UDC $547.39 ' 5+547.427 .1+547.422 .22+547.718$

K.I. Kuznetsova, V.B. Vostres, R.I. Fleychuk, O.I. Hevus

\title{
SYNTHESIS OF SURFACE-ACTIVE MONOMERS AND PEROXIDES ON THE BASIS OF DISUBSTITUTED OXETANE
}

\author{
Lviv Polytechnic National University, Lviv, Ukraine
}

\begin{abstract}
A series of novel surfactants on the basis of pentaerythritol derivatives and 3,3-disubstituted oxetanes basis was synthesized. Among other substances, a nonionic peroxy surfactant containing a polyethylene glycol fragment was prepared by the interaction of bromo dihydroperoxide (a pentaerythritol derivative) with polyethylene glycol methyl ether. The consequent transformations of 2,2-di[(tert-butylperoxy)methyl]propan-1,3-diol, through the stages of the formation of dimaleate with the participation of two hydroxyl groups, the formation of acyl dichloride and a further reaction with polyethylene glycol, yields a goal peroxy surface-active monomer belonging to asymmetric esters of maleic acid. A nonionic surfactant containing a residual of higher fatty acid and a polyethylene glycol fragment was prepared by the esterification of a dihydroxy substituted oxetane with oleic acid and the subsequent oxetane ring opening of the obtained monoethylated polyethylene glycol diester. The effects of the reaction conditions on the yield and the composition of interaction products were investigated. The dependences of the surface tension of aqueous solutions of the obtained surfactants on their concentrations were established; the values of critical micelle concentrations were determined.
\end{abstract}

Keywords: pentaerythritol, disubstituted oxetanes, inisurfmer, polyethylene glycol methyl ether, surfactants.

DOI: $10.32434 / 0321-4095-2019-123-2-5-11$

\section{Introduction}

Today the surfactants are of increasing importance in biology, medicine, technics, etc. A number of relevant surfactants have been consumed intensively for the production of novel curing agents [1], contemporary composites and nanomaterials [2].

The properties of such composites are associated with microheterogeneity of their structure and determined by the processes occurring at an interface and the properties of formed interfacial layers [3]. Functional surface-active monomers and initiators, i.e. parmers and inisurfs, are widely used to construct interfacial layers and to influence in this way the properties of composites. These compounds are predominantly located at an interface due to their surface activity and act as surfactants, which stabilizes colloid systems. Owing to the existence of corresponding functions, i.e. polymerizable $\mathrm{C}=\mathrm{C}$ bonds or an oxetane cycle as well as peroxy groups, they can act as monomers or initiators in polymerizations. This permits forming polymeric layers with necessary functional groups directly at an interface.

So, there is a need for novel available functional surfactants of different types (nonionic, cationic and anionic) which contain polymerizable fragments and/ or initiator centers and can display a necessary surface activity in a wide range of temperature, $\mathrm{pH}$ and ionic strength of a medium [3].

Inisurfmers are a valuable group of surfaceactive monomers; they are compounds which simultaneously contain a polymerizable fragment and an initiator center, predominantly a peroxy group, able to generate free radicals in a given temperature range. These functions can be located either in a hydrophilic or in a hydrophobic block of a surfactant.

There are many literary sources concerning the preparation and surface-activity of different surfactants (including that with peroxy groups) and offering the ways and methods for their application [4-7].

We suggest that pentaerythritol derivatives, and specifically functional 3,3-disubstituted oxetanes, which are widely used in the organic synthesis [8] 
and can serve as perspective starting compounds for the synthesis of novel polyfunctional surfactants. The existent reactive centers in their molecules of different nature permit obtaining various types of polyfunctional compounds (monomers, initiators and surfactants) due to the consequent transformations with different reagents.

\section{Result and discussion}

\section{Synthesis of surfactants}

We earlier synthesized inisurfmers using asymmetric esters of maleic acid derived from maleic anhydride, including hydroxyperoxides and polyethylene glycols which contain both an $\omega$-tertbutylperoxy alkyl fragment as a hydrophobic moiety and a polyethylene glycol chain of different lengths as a hydrophobic one [9]. The physicochemical properties of these compounds, especially solubility and surface-activity, can be varied in a wide range by altering the relationships between the lengths of alkyl and polyethylene oxide substitutors.

The application of functional oxetanes as starting materials may significantly widen the possibilities of the construction of functional surfaceactive monomers and initiators with the necessary combination of colloid properties and reactivity. Thus, Kropf and Torkler used the reaction of tertbutyl hydroperoxide (TBHP) with 2,6-dioxaspiro[3.3] heptane and 3,3-bis(chloromethyl)oxetane to prepare hydroxy mono- and diperoxides [10]. The functional oxetanes which contain the primary hydroxy groups and/or a reactive halide atom can be easily obtained from pentaerythritol. So, starting 3-(bromomethyl)-3-(hydroxymethyl)oxetane (II) was got from pentaerythritol according to the known method [11] via two stages. At first, pentaerythrityl dibromide (I) was obtained by the action of hydrobromic acid on pentaerythritol; the further dehydrogenation with sodium ethanolate gave purposive oxetane (II) (Scheme 1).

The peroxy pentaerythritol derivatives, namely peroxy oxetane (III), dihydroxybromoalkyl peroxide
(IV) and dihydroxy diperoxide (V), were obtained according to the discribed method [10] by the peroxidolysis of oxetane (II) with TBHP (Scheme 1).

Basic aluminium oxide was employed as a catalyst. The interaction was carried out in tetrahydrofuran at $20^{\circ} \mathrm{C}$ for $84-230 \mathrm{~h}$ in argon. The course of the reaction was controlled by a thin-layer chromatography (TLC).

Oxetane (II) contains three reactive centres in the molecule (the bromomethyl and the hydroxymethyl group as well as the oxetane cycle) which are able to react with nucleophilic reagents. TBHP exhibits strong nucleophility in a basic medium, substitutes the bromide atom and simultaneously opens the oxetane ring. The oxetane (II) hydroxyl does not interact with TBHP under such conditions. Hence, hydroxyperoxide (III) is formed owing to the reaction of TBHP with oxetane (II) and it is a product of the bromide atom substitution; bromo dihydroxyperoxide (IV) is a product of the oxetane ring opening; diperoxide (V) is formed due to the reaction with both reactive centers (Scheme 1).

The maximum content of hydroxyperoxide (III) in the reaction mixture reached $45 \%$ after $84 \mathrm{~h}$. As the duration of the reaction was extended up to $90-$ $100 \mathrm{~h}$, the total peroxide (III) and (IV) contents in the reaction mixture did not increase significantly; an increase in the diperoxide (V) content was observed. As the duration of the reaction was subsequently extended to $230 \mathrm{~h}$, the yields of peroxide (III) and (IV) decreased; the yield of compound (V) increased and was equal to $37 \%$.

This can be accounted for the fact that the starting oxetane has been exhausted, which was achieved after $90 \mathrm{~h}$ of the process and the TBHP excess subsequently reacts with compounds (III) and (IV). Further increasing the catalyst content (basic aluminium oxide) and the temperature (up to $35^{\circ} \mathrm{C}$ ) did not significantly affect the composition of reaction mixture.

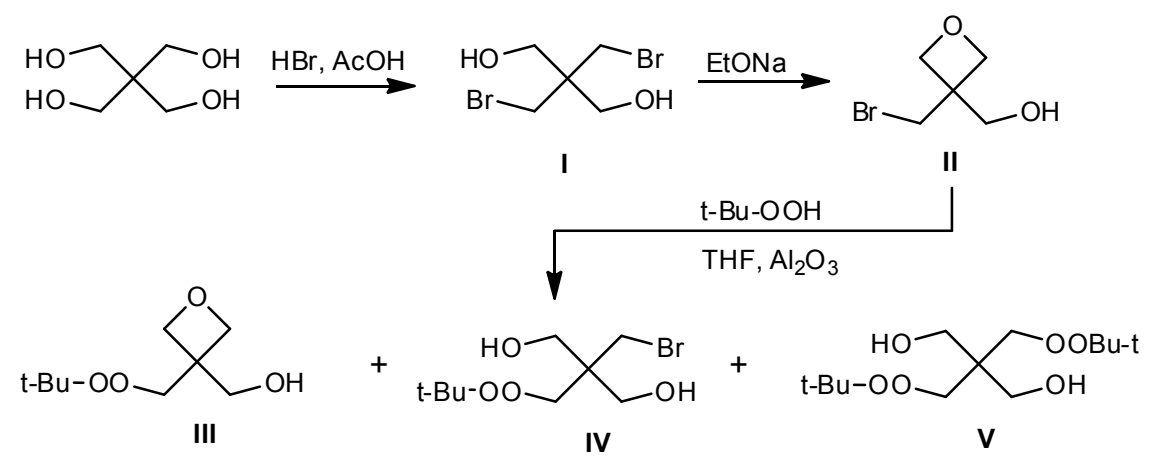

Scheme 1 
Peroxides (IV, V) were used as starting compounds to prepare nonionic polymerizable surface-active peroxides (inisurfmers). The nonionic peroxy surfactant with a polyethylene glycol fragment was gained by the Williamson ether synthesis from polyethylene glycol methyl ether (Me-PEG-350) and bromo dihydroxyperoxide (IV) in the presence of a phase-transfer catalyst [12] (Scheme 2).

The alkylation was carried out in a two-phase system, the solution of the reagents in dichloromethane-sodium hydroxide $50 \%$ solution in water, at the temperature of $40^{\circ} \mathrm{C}$. Tetrabutylammonium iodide (TBAI) was used as a phase-transfer catalyst. The reaction was completed in $3 \mathrm{~h}$ on the whole under these conditions. The yield of compound (VI) was $68 \%$.

Peroxy bis-maleate (IX) was obtained in three steps (Scheme 3).

At first, dimaleate (VII) was obtained by the interaction of diperoxide (V) with 2 moles of maleic anhydride in chloroform in the presence of catalytic amount of triethylamine (TEA) at $35-40^{\circ} \mathrm{C}$ for $18 \mathrm{~h}$.

At the next step, the reaction of dimaleate (VII) with phosphorus trichloride yields intermediate acyl chloride (VIII); it subsequently interacted with the eight-fold excess of polyethylene glycol (PEG-300) at $0-5^{\circ} \mathrm{C}$ in benzene with the use of TEA as a hydrogen chloride scavenger; as a result, peroxy surfmer (IX) was obtained. The application of a mentioned high excess of PEG was necessary to avoid the formation of oligomeric products due to the PEG diacylation with the acyl chloride.

Acyl chloride (VIII) solution was dripped to the PEG and TEA solution. Resulting inisurfmer (IX) was purified by the repeated extraction with butan-2-one from the aqueous solution. The yield was $82 \%$.

Oxetane diol $(\mathrm{X})$ is of deep interest because it as a polyfunctional reagent for the preparation of organic compounds of different classes, viz., the surfactants of various types. It was synthesized from pentaerythritol according to the methods described elsewhere [13,14].

Nonionic surfactant (XI) containing higher fatty acid remains was synthesized according to the Steglich esterification from oxetane diol (X) and oleic acid in chloroform. 1,3-Dicyclohexylcarbodiimide (DCC) and 1,4-diazabicyclo[2.2.2]octane (DABCO) were used as a dehydrant and a catalyst, respectively. This permitted obtaining diester (XI) practically with a quantitative yield (Scheme 4).

The Steglich esterification was chosen because

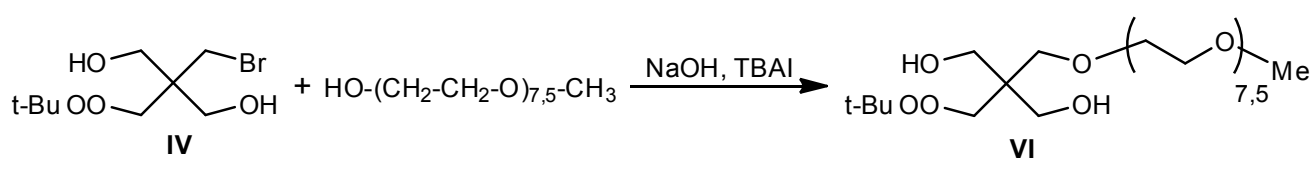

Scheme 2

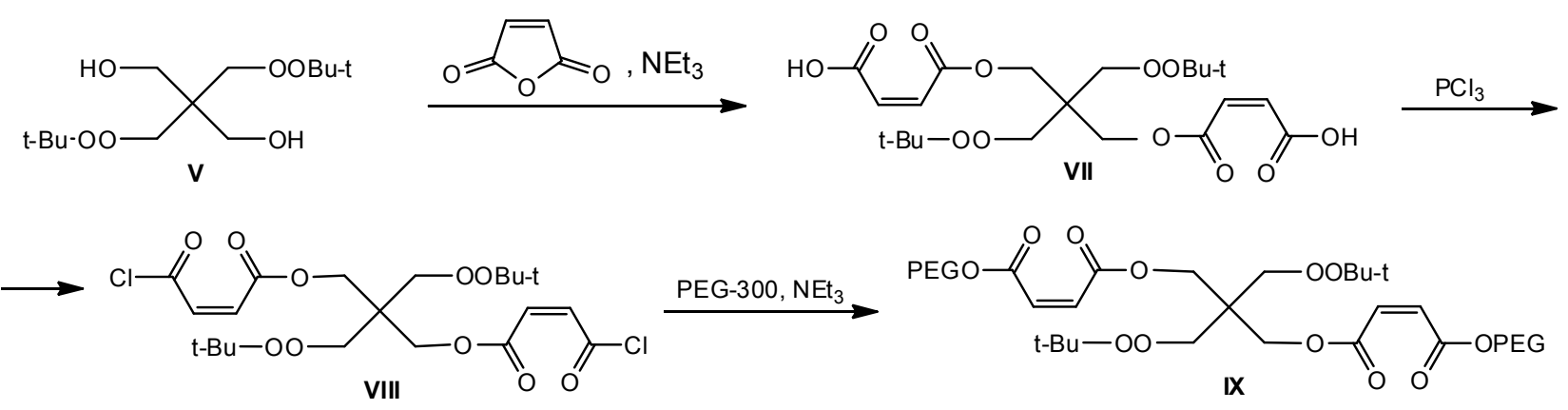

Scheme 3

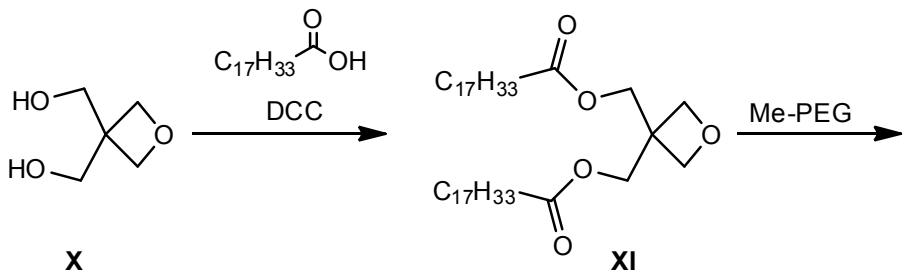

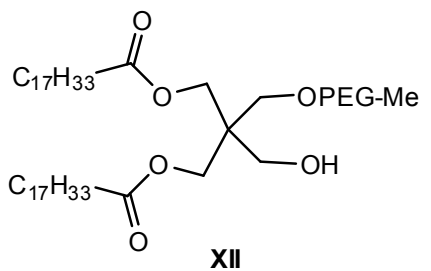

Scheme 4 
the oxetane cycle does not take effect with carboxylic acids under such condition in contrast to the acid catalysis.

Me-PEG-350 was used to introduce a nonionic block into diester (XI) (Scheme 4). The oxetane cycle was opened in toluene in the presence of sulfuric acid as a catalyst at $0-5^{\circ} \mathrm{C}$ according to the method described elsewhere [15]. The yield of the goal surfactant was practically quantitative. It should be noted that increasing the temperature and the reaction duration caused the appearance of oligomeric products in the reaction mixture.

Surface activity of the prepared compounds

The molecules of synthesized compounds (VI, VII and XII) are composed of the hydrophilic and the hydrophobic blocks with various lengtsh; thus they can exhibit the properties of a typical surfactant. We determined the surface tension of the synthesized compounds (VI) and (XII) versus their concentrations at an interface «aqueous solutionair» at the temperature of $20^{\circ} \mathrm{C}$ (Figure).

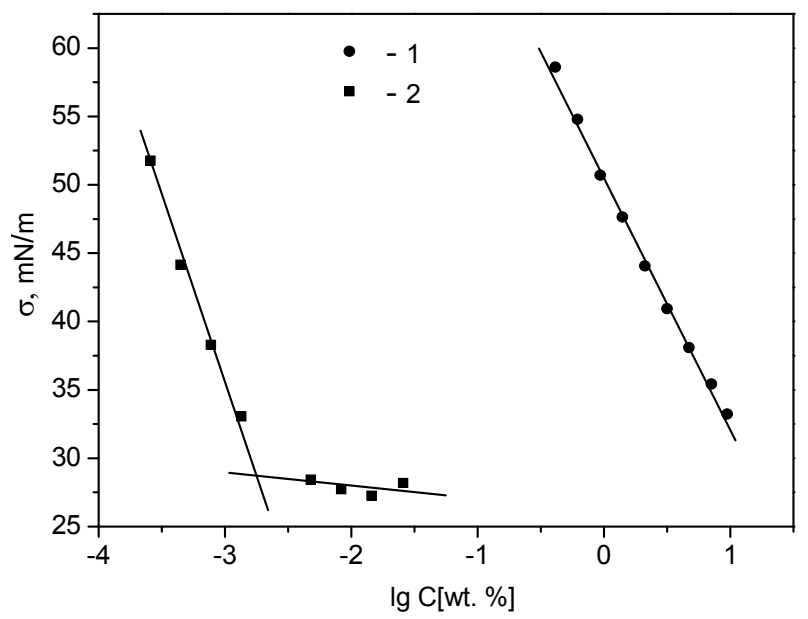

The isotherms of surface tension of aqueous solution containing peroxy dihydroxy ester (VI) (1) and dioleate (XII) (2)

It can be seen that the isotherms of surface tension for the compounds (VI) and (XII) are different. The isotherm of surface tension of peroxy diester (VI) (curve 1) has a linear shape in a semilogarithmic scale. The surface tension of the aqueous solution decreases with an increase in the concentration. This is due to the formation of molecular solution up to the concentration which corresponds to the saturated solution. This compound forms a separate macrophase above that concentration.

At the same time, monomer (XII) exhibits the properties of a typical surfactant (curve 2). The more the concentration increases, the less is the surface tension. When the critical micelle concentration (CMC) is achieved, the surface tension does not vary significantly. The inflection point for the compound (XII) shows that the CMC equals $0.0017 \mathrm{wt} . \%$ or $1.77 \cdot 10^{-5} \mathrm{~mol} \mathrm{dm}^{-3}$ and the surface tension at the concentrations above the $\mathrm{CMC}$ is equal to $28.9 \mathrm{mN} \mathrm{m}^{-1}$. A relative low $\mathrm{CMC}$ of the compound (XII) is connected with the existence of two oleic acid residues in the molecule which enhance its hydrophobic nature. This decreases the solubility of the monomer in water; that is why it begins to form micelles at low concentrations.

\section{Experimental part}

We used chemically pure grade solvents and they were glass-distilled prior to use. Pentaerythritol was of the technical grade and used without any purification. Triethylamine, oleic acid, sulfuric acid, glacial acetic acid were chemically pure. DCC was produced by «Alpha Aesar», DABCO was produced by «Aldrich». Me-PEG-350 (with an average molecular weight of $350 \mathrm{~g} / \mathrm{mol}$ ), PEG-300 (with an average molecular weight of $300 \mathrm{~g} / \mathrm{mol}$ ) («Aldrich») were desiccated in vacuo at $80-100^{\circ} \mathrm{C}$ up to reach a constant weight.

The individuality of the synthesized compounds and the course of the reactions was controlled by a TLC at the silica gel $60 \mathrm{~F}_{254}$ («Merck») plates. $\mathrm{H}^{1}$ NMR spectra were recorded using the «Bruckner 150» instrument in $\mathrm{CDCl}_{3}$ at an operating frequency of $300 \mathrm{MHz}$; the concentration of samples was $5-10 \%$, hexamethyldisiloxan was an internal standard. Molecular weights were determined by cryoscopy in benzene, the surface tension of aqueous solutions of the synthesized surfactants was determined by the Du Noüy method.

Pentaerythrityl dibromide (I) was obtained by the reaction of $27.3 \mathrm{~g}(0.2 \mathrm{~mol})$ of pentaerythritol with $48 \%$ hydrobromic acid according to the procedure described elsewhere [11]. The yield was 31.0 g, m.p. $110-111^{\circ} \mathrm{C}$.

3-(Bromomethyl)-3-(hydroxymethyl)oxetane (II) was prepared by the interaction of sodium ethanolate, which was obtained by dissolving of $0.64 \mathrm{~g}(0.028 \mathrm{~mol})$ of sodium in $32 \mathrm{~mL}$ of absolute ethanol, with $8.23 \mathrm{~g}(0.028 \mathrm{~mol})$ of pentaerythrityldibromide (I) in absolute ethanol according to the procedure described elsewhere [11]. The yield was $7.63 \mathrm{~g}(68 \%)$, b.p. $141-142^{\circ} \mathrm{C}(1-2 \mathrm{~mm} \mathrm{Hg})$. Calculated for $\mathrm{C}_{5} \mathrm{H}_{9} \mathrm{O}_{2} \mathrm{Br}, \%$ : C 33.17; $\mathrm{H} 5.01 ; \mathrm{Br}$ 44.14. Found, \%: C 33.12; H 5.0; $\mathrm{Br} 43.94 .{ }^{1} \mathrm{H}$ NMR $\left(\mathrm{CDCl}_{3}\right), \delta$, ppm: $2.85(\mathrm{t}, \mathrm{J}=5.4 \mathrm{~Hz}, 1 \mathrm{H},-\mathrm{OH})$, $3.89\left(\mathrm{~d}, \mathrm{~J}=5.3 \mathrm{~Hz}, 2 \mathrm{H},-\mathrm{CH}_{2}-\mathrm{OH}\right), 3.83(\mathrm{~s}, 2 \mathrm{H},-$ 
$\mathrm{CH}_{2}-\mathrm{Br}$ ), 4.29, 4.34 (AB quartet, $\mathrm{J}=5.9 \mathrm{~Hz}, 4 \mathrm{H}$, $\mathrm{CH}_{2} \mathrm{O}$, oxetane ring).

$\{3-[($ tert-Butylperoxy)methyl]oxetan-3yl\}methanol (III). The mixture of $2.0 \mathrm{~g}$ of aluminium oxide, $9 \mathrm{~mL}$ of tetrahydrofuran and $0.202 \mathrm{~g}$ $(0.0025 \mathrm{~mol})$ of TBHP was stirred for $2 \mathrm{~min}$ in argon; $0.135 \mathrm{~g}(0.0075 \mathrm{~mol})$ of oxetane (II) in $10 \mathrm{~mL}$ of dichloromethane was added and additionally stirred at $20^{\circ} \mathrm{C}$ for $84 \mathrm{~h} .250 \mathrm{~mL}$ of ethanol was added and placed into a refrigerator for $12 \mathrm{~h}$. The suspension was filtered using a silica gel layer and washed with ethanol. The solvent was evaporated and chromatography using silica gel (the eluent was dichloromethane-diethyl ether mixture $(5: 1))$ gave 0.64 g $(45 \%)$, m.p. $16.0-17.5^{\circ} \mathrm{C}$. Molecular weight: found 190, calculated 201.5. Calculated for $\mathrm{C}_{9} \mathrm{H}_{18} \mathrm{O}_{4}$, $\%$ : C 56.82; H 9.54. Found, \%: C 56.88; $\mathrm{H} \mathrm{9.51.}{ }^{1} \mathrm{H}$ NMR $\left(\mathrm{CDCl}_{3}\right), \delta$, ppm: $1.27\left(\mathrm{~s}, 9 \mathrm{H}, \mathrm{C}\left(\mathrm{CH}_{3}\right)_{3}\right), 2.88$ (t, J=5.3 Hz, 1H, -OH $), 3.89(\mathrm{~d}, \mathrm{~J}=5.4 \mathrm{~Hz}, 2 \mathrm{H},-$ $\left.\mathrm{CH}_{2}-\mathrm{OH}\right), 4.28\left(\mathrm{~s}, 2 \mathrm{H}, \mathrm{CH}_{2}-\mathrm{OOC}\left(\mathrm{CH}_{3}\right)_{3}\right), 4.31$, 4.45 ( $\mathrm{AB}$ quartet, $\mathrm{J}=5.8 \mathrm{~Hz}, 4 \mathrm{H}, \mathrm{CH}_{2} \mathrm{O}$, oxetane ring).

2-(Bromomethyl)-2-(tert-butylperoxymethyl)propane-1,3-diol (IV) was prepared from $0.13 \mathrm{~g}$ $(0.0075 \mathrm{~mol})$ of oxetane (II) and $0.20 \mathrm{~g}(0.0025 \mathrm{~mol})$ of TBHP by the procedure similar to that using for the preparation of compound (III). The yield was $0.25 \mathrm{~g}(35 \%)$. Molecular weight: found 285 , calculated 287.17. Calculated for $\mathrm{C}_{9} \mathrm{H}_{19} \mathrm{O}_{6}, \%$ : C 37.64; $\mathrm{H}$ 6.67; $\mathrm{Br} 27.83$. Found, \%: $\mathrm{C} 37.71 ; \mathrm{H}$ 6.60; $\mathrm{Br} 27.77 .{ }^{1} \mathrm{H}$ NMR $\left(\mathrm{CDCl}_{3}\right), \delta$, ppm: 1.28 (s, $\left.9 \mathrm{H},\left(\mathrm{CH}_{3}\right)_{3} \mathrm{C}-\right), 2.62(\mathrm{t}, \mathrm{J}=7.2 \mathrm{~Hz}, 2 \mathrm{H},-\mathrm{OH}), 3.45$ (d, J=7.3 Hz, 4H, $\left.-\mathrm{CH}_{2}-\mathrm{OH}\right), 3.86\left(\mathrm{~s}, 2 \mathrm{H},-\mathrm{CH}_{2}-\right.$ $\mathrm{Br}$ ), 4.81 (s, $\left.4 \mathrm{H},-\mathrm{C}-\mathrm{CH}_{2}-\mathrm{OO}\right)$.

2,2-Di[(tert-butylperoxy)methyl]propane-1,3diol (V) was prepared by the method similar to that using for the preparation of compound (III) from $0.404 \mathrm{~g}(0.005 \mathrm{~mol})$ of TBHP and $0.23 \mathrm{~g}(0.00125 \mathrm{~mol})$ of oxetane (II) in $9 \mathrm{~mL}$ of tetrahydrofuran at $20^{\circ} \mathrm{C}$ for $230 \mathrm{~h}$. The yield was $0.25 \mathrm{~g}(37 \%)$, m.p. 29$30^{\circ} \mathrm{C}$. Molecular weight: found 283 , calculated 280.36. Calculated for $\mathrm{C}_{13} \mathrm{H}_{28} \mathrm{O}_{6}$, \%: C 55.69; $\mathrm{H} \mathrm{10.07.}$ Found, \%: C 55.83; $\mathrm{H} 10.11 .{ }^{1} \mathrm{H}$ NMR $\left(\mathrm{CDCl}_{3}\right), \delta$, ppm: $1.27\left(\mathrm{~s}, 18 \mathrm{H},-\mathrm{C}\left(\mathrm{CH}_{3}\right)_{3}\right), 2.61(\mathrm{t}, \mathrm{J}=7.6 \mathrm{~Hz}$, $2 \mathrm{H},-\mathrm{OH}), 4.05\left(\mathrm{~d}, \mathrm{~J}=5.6 \mathrm{~Hz}, 4 \mathrm{H},-\mathrm{CH}_{2}-\mathrm{OH}\right)$, 4.81 (s, 4H, $-\mathrm{C}-\mathrm{CH}_{2}-\mathrm{OO}-$ ).

Monoether (VI). The solution containing $5.25 \mathrm{~g}(0.015 \mathrm{~mol})$ of Me-PEG-350 and $0.2 \mathrm{~g}$ of TBAI in dichloromethane was mixed with $1.5 \mathrm{~mL}$ of $50 \%$ sodium hydroxide solution in water for $30 \mathrm{~min}$; then, $4.30 \mathrm{~g}(0.015 \mathrm{~mol})$ of dihydroxybromoalkyl peroxide (IV) was added and stirred for $2.5 \mathrm{~h}$ at $40^{\circ} \mathrm{C}$. The aqueous phase was extracted with dichloromethane and the solvent was evaporated.
The yield of the purposive monoether was $11.73 \mathrm{~g}$ (68\%). Molecular weight: found 1150; calculated $1150 ; \mathrm{d}_{4}^{20} 1.0850 ; \mathrm{n}_{\mathrm{D}}^{20} 1.4427$. Calculated for $\mathrm{C}_{42.6} \mathrm{H}_{88.2} \mathrm{O}_{21.3}, \%$ : C 44.45; H 7.67. Hydroxyl number 97.39. Found. \%: C 45.62; H 7.51. Hydroxyl number 97.4. ${ }^{1} \mathrm{H}$ NMR $\left(\mathrm{CDCl}_{3}\right), \delta$, ppm: $1.02(\mathrm{~s}, 3 \mathrm{H},-\mathrm{O}-$ $\left.\mathrm{PEG}-\mathrm{CH}_{3}\right), 1.28\left(\mathrm{~s}, 9 \mathrm{H},-\mathrm{C}\left(\mathrm{CH}_{3}\right)_{3}\right), 2.61(\mathrm{t}, \mathrm{J}=8$ $\mathrm{Hz}, 2 \mathrm{H},-\mathrm{OH}), 3.42-3.44 \mathrm{~m}(\approx 30 \mathrm{H}$, PEG chain $)$, $4.05\left(\mathrm{~d}, \mathrm{~J}=8 \mathrm{~Hz}, 2 \mathrm{H},-\mathrm{CH}_{2}-\mathrm{OH}\right), 4.81(\mathrm{~s}, 4 \mathrm{H},-$ $\left.\mathrm{C}-\mathrm{CH}_{2}-\mathrm{O}-\right)$.

2, 2 -di[ ( tert-Butylperoxy)methyl] trimethylenedimaleate (VII). $1.07 \mathrm{~g}(0.0109 \mathrm{~mol})$ of maleic anhydride was added to the solution containing $1.53 \mathrm{~g}(0.0054 \mathrm{~mol})$ of dihydroxyperoxide (V) and $0.01 \mathrm{~g}$ of TEA in $50 \mathrm{~mL}$ of chloroform. The mixture was kept for $18 \mathrm{~h}$ at $35-40^{\circ} \mathrm{C}$. The solvent was evaporated and the residue was recrystallized from ethyl acetate to give $2.23 \mathrm{~g}(67 \%)$ of the diperoxydimaleate. Molecular weight: found 483, calculated 476.47. Calculated for $\mathrm{C}_{21} \mathrm{H}_{32} \mathrm{O}_{12}, \%$ : C 52.94; H 6.77. Found, \%: C 53.02; H 6.70. ${ }^{1} \mathrm{H}$ NMR $\left(\mathrm{CDCl}_{3}\right), \delta$, ppm: $1.20\left(\mathrm{~s}, 18 \mathrm{H},-\mathrm{C}\left(\mathrm{CH}_{3}\right)_{3}\right), 3.49$ (s, $\left.4 \mathrm{H},\left(\mathrm{CH}_{3}\right)_{3}-\mathrm{OO}-\mathrm{CH}_{2}-\right), 3.65(\mathrm{~d}, \mathrm{~J}=8 \mathrm{~Hz}, 4 \mathrm{H},-$ $\left.\mathrm{C}-\mathrm{CH}_{2}-\mathrm{O}-\mathrm{C}(\mathrm{O})-\mathrm{C}\right), 6.43\left(\mathrm{dd}, \mathrm{J}=7.3 \Gamma_{ц}, 4 \mathrm{H}\right.$, $\mathrm{C} \underline{H}=\mathrm{C} \underline{H}-), 10.32(\mathrm{~s}, 2 \mathrm{H},-\mathrm{C}(\mathrm{O})-\mathrm{OH})$.

Acyl dichloride (VIII). The solution containing $2.11 \mathrm{~g}(0.0045 \mathrm{~mol})$ of diperoxydimaleate (VII) in a dichloromethane-dimethylformamide mixture was treated with $4.94 \mathrm{~g}(0.036 \mathrm{~mol})$ of $\mathrm{PCl}_{3}$ at stirring at the temperature of $0-5^{\circ} \mathrm{C}$ and kept at room temperature for $12 \mathrm{~h}$. The phosphorous acid was discarded and the solvent was evaporated. The yield of the acyl dichloride was $2.07 \mathrm{~g}$. The obtained product was further used without any purification.

Surfmer (IX). The solution containing $4.80 \mathrm{~g}$ $(0.016 \mathrm{~mol})$ of PEG-300 and $0.21 \mathrm{~g}(0.0021 \mathrm{~mol})$ TEA in $20 \mathrm{~mL}$ of benzene was treated with $1.06 \mathrm{~g}$ $(0.002 \mathrm{~mol})$ of acyl dichloride (VIII) at $5^{\circ} \mathrm{C}$. The mixture was stirred for $7 \mathrm{~h}$, heated to a room temperature and additionally kept for $14 \mathrm{~h}$. The settled triethylammonium chloride was filtered away; the solvent evaporated and $25 \mathrm{~mL}$ of water was added. The surfmer was isolated from the PEG excess by the extraction with butan-2-one at $80^{\circ} \mathrm{C}$. The evaporation of the butan-2-one gave $1.7 \mathrm{~g}$ of the surfmer (82\%). Molecular weight: found 975.35; calculated 1039.2. Calculated for $\mathrm{C}_{46.6} \mathrm{H}_{83.2} \mathrm{O}_{24.8}, \%$ : $\mathrm{C} 53.81 ; \mathrm{H} 8.01$. Found, \%: C 52.97; $\mathrm{H} 7.87 .{ }^{1} \mathrm{H}$ NMR $\left(\mathrm{CDCl}_{3}\right), \delta$, ppm: $1.20\left(\mathrm{~s}, 18 \mathrm{H},\left(\mathrm{CH}_{3}\right)_{3} \mathrm{C}-\right)$, $3.49\left(\mathrm{~s}, 2 \mathrm{H},\left(\mathrm{CH}_{3}\right)_{3}-\mathrm{OO}-\mathrm{CH}_{2}-\mathrm{C}-\right), 3.65(\mathrm{~s}, 2 \mathrm{H}$, $\left.-\mathrm{C}-\mathrm{CH}_{2}-\mathrm{O}-\right), 3.6(\mathrm{~m}, \approx 25 \mathrm{H}$, PEG chain), 6.31 $(\mathrm{dd}, \mathrm{J}=7.3 \mathrm{~Hz}, 4 \mathrm{H},-\mathrm{CH}=\mathrm{CH}-$ ).

3,3-di(Hydroxymethyl)oxetane (X) was obtained from $13.0 \mathrm{~g}(0.23 \mathrm{~mol})$ potassium hydroxide 
and $39.8 \mathrm{~g}(0.2 \mathrm{~mol})$ 2-(bromomethyl)-2-(hydroxymethyl)propan 1,3-diol according to the procedure described elsewhere [14]. The yield was $14.0 \mathrm{~g}$ of the purposive product. B.p. $136-139^{\circ} \mathrm{C}(1-2 \mathrm{~mm}$ $\mathrm{Hg})$. (Lit. b.p. $\left.128^{\circ} \mathrm{C}(0.4 \mathrm{~mm} \mathrm{Hg},[14])\right) .{ }^{1} \mathrm{H}$ NMR $\left(\mathrm{CDCl}_{3}\right), \delta$, ppm: $3.75\left(\mathrm{t}, \mathrm{J}=5.9 \mathrm{~Hz}, 2 \mathrm{H}, \mathrm{CH}_{2} \mathrm{OH}\right)$, $4.27\left(\mathrm{~s}, 4 \mathrm{H}, \mathrm{CH}_{2} \mathrm{O}\right.$ oxetane ring $), 4.54(\mathrm{~d}, \mathrm{~J}=5.9$ $\left.\mathrm{Hz}, 4 \mathrm{H}, \mathrm{CH}_{2} \mathrm{OH}\right)$.

3,3-di-(cis-9-Octadecynoyloxymethyl)oxetane (XI). The solution containing $10.3 \mathrm{~g}(0.05 \mathrm{~mol})$ of DCC in $30 \mathrm{~mL}$ of chloroform was added to the solution containing $14.2 \mathrm{~g}(0.05 \mathrm{~mol})$ of oleic acid in $20 \mathrm{~mL}$ of chloroform at $5^{\circ} \mathrm{C}$; the mixture was stirred for $1 \mathrm{~h}$ and dripped to the solution containing $2.95 \mathrm{~g}(0.025 \mathrm{~mol})$ of dihydroxymethyloxetane $(\mathrm{X})$ and $1.0 \mathrm{~g}$ of DABCO in $15 \mathrm{~mL}$ of chloroform. The reaction mixture was agitated for $2 \mathrm{~h}$ at $5-20^{\circ} \mathrm{C}$; the settled dicyclohexylurea was filtered away and the solvent was evaporated to give $16.1 \mathrm{~g}$ of the purposive product. The yield was practically quantitative. Molecular weight: found 657; calculated 647. Calculated for $\mathrm{C}_{41} \mathrm{H}_{74} \mathrm{O}_{5}$, \%: C 76.11; $\mathrm{H}$ 11.53. Found, \% :C 76.41; $\mathrm{H} 11.98 .{ }^{1} \mathrm{H}$ NMR $\left(\mathrm{CDCl}_{3}\right), \delta$, ppm: 0.89 (t, J=6.9 Hz, 6H, $\left.-\left(\mathrm{CH}_{2}\right)_{\mathrm{n}} \mathrm{CH}_{3}\right), 1.35$ $\left(\mathrm{m}, 40 \mathrm{H}\right.$, aliphatic $\left.-\mathrm{CH}_{2}-\right), 1.63(\mathrm{~m}, \mathrm{~J}=7.1 \mathrm{~Hz}$, $\left.4 \mathrm{H},-\mathrm{CH}_{2}-\mathrm{CH}_{2}-\mathrm{C}(\mathrm{O})-\right), 2.01\left(\mathrm{~m}, 8 \mathrm{H},-\mathrm{CH}_{2}-\right.$ $\left.\mathrm{CH}=\mathrm{CH}-\mathrm{CH}_{2}-\right), 2.4\left(\mathrm{t}, \mathrm{J}=7.1 \mathrm{~Hz}, 4 \mathrm{H},-\mathrm{CH}_{2}-\right.$ $\mathrm{C}(\mathrm{O})-$ ), 3.65 (s, $4 \mathrm{H},-\mathrm{O}-\mathrm{CH}_{2}-\mathrm{C}$-oxetane chain), 4.45 (s, $4 \mathrm{H},-\mathrm{CH}_{2}-\mathrm{O}$-oxetane ring), 5.3 (ddd, $\mathrm{J}=5.1$, $\left.3.7,1.5 \mathrm{~Hz}, 4 \mathrm{H},-\mathrm{CH}_{2}-\mathrm{CH}=\mathrm{CH}-\mathrm{CH}_{2}-\right)$.

2-(Hydroxymethyl) - 2-( $\omega$-methylpolyethyleneglycoloxymethyl)propane-1,3-diyl dioleate (XII). $0.025 \mathrm{~mL}$ of concentrated sulfuric acid was added to the solution containing $5.25 \mathrm{~g}(0.015 \mathrm{~mol})$ of Me-PEG-350 and $10.0 \mathrm{~g}(0.015 \mathrm{~mol})$ of diester (XI) in $20 \mathrm{~mL}$ of toluene at $0-5^{\circ} \mathrm{C}$; the mixture was and stirred for $24 \mathrm{~h}$. The sulfuric acid was neutralized by sodium carbonate and the precipitate was centrifuged. The solvent was evaporated to give 14.5 $\mathrm{g}$ of the purposive surfactant. The yield was practically quantitative. Molecular weight: foud 994; calculated 972.2. Calculated for $\mathrm{C}_{34.4} \mathrm{H}_{106.8} \mathrm{O}_{13.2}, \%$ : C 67.15; H 10.99. Found, \%: $\mathrm{C} 67.57 ; \mathrm{H} 10.45$. ${ }^{1} \mathrm{H}$ NMR $\left(\mathrm{CDCl}_{3}\right), \delta$, ppm: $0.89\left(\mathrm{t}, 6 \mathrm{H},-\left(\mathrm{CH}_{2}\right)_{\mathrm{n}} \mathrm{CH}_{3}\right), 1.02$ $\left(\mathrm{s}, 3 \mathrm{H},-\mathrm{O}-\mathrm{PEG}-\mathrm{CH}_{3}\right), 1.27-1.35(\mathrm{~m}, 40 \mathrm{H}$, aliphatic $\left.-\mathrm{CH}_{2}-\right), 1.63\left(\mathrm{~m}, 4 \mathrm{H},-\mathrm{CH}_{2}-\mathrm{CH}_{2}-\right.$ $\mathrm{C}(\mathrm{O})-), 2.01\left(\mathrm{~m}, 8 \mathrm{H},-\mathrm{CH}_{2}-\mathrm{CH}=\mathrm{CH}-\mathrm{CH}_{2}-\right), 2.4$ (t, $\left.4 \mathrm{H},-\mathrm{CH}_{2}-\mathrm{C}(\mathrm{O})-\right), 3.42-3.44(\mathrm{~m}, \approx 29 \mathrm{H}, \mathrm{PEG}$ chain), $3.75\left(\mathrm{t}, 1 \mathrm{H}, \mathrm{CH}_{2} \mathrm{OH}\right), 4.05\left(\mathrm{~d}, 2 \mathrm{H},-\mathrm{CH}_{2}-\right.$ $\mathrm{OH}), 5.34(\mathrm{~m}, 4 \mathrm{H},-\mathrm{C} \underline{\mathrm{H}}=\mathrm{C} \underline{\mathrm{H}}-)$.

\section{Conclusions}

We synthesized a series of novel nonionic surfactants based on pentaerythritol, the products of its transformations and disubstituted oxetanes, including those containing peroxy groups. The isotherms of surface tension at an air-aqueous solution interface were plotted for the obtained compounds; the CMC was determined.

\section{REFERENCES}

1. Malmsten M. Surfactants and polymers in drug delivery. - CRC Press, 2002. - 368 p.

2. Bahatofunktsional'ni nanomaterialy dl'ya biologii i medytsyny: molekuliarnyi dyzain, syntez i zastosuvannia (za redaktsiyeyu chl.-korespondenta NAN Ukrainy R.S. Stoika). Kyiv: Naukova dumka, 2017. - 363 p.

3. Hevus O.I. Funktsional'ni poverkhnevo-aktyvni peroxidy i monomery yak reagenty dl'ya oderzhann'ya reaktsiinozdatnykh modyfikatoriv poverkhni: Dys....dokt. khim. nauk. - Lviv: Lviv Polytechnic National University, 2010.

4. Borzenkov M., Hevus O. Surface active monomers. Synthesis, properties, and application. - New York: Springer, 2014. -67 p.

5. Researches in amphiphilic properties of copolyesters with chromophore groups / Yakoviv M, Fihurka N., Nosova N., Samaryk V., Vasylyshyn T., Hermanovych S., Voronov S., Varvarenko S. // Chem. Chem. Technol. - 2018. - Vol.12. No. 3. - P.318-325.

6. Reactive polymers on the basis of functional peroxides / R. Fleychuk, A. Kohut, O. Hevus, S. Voronov // Macromol. Symp. - 2004. - Vol.210. - No. 1. - P.85-92.

7. Synthesis and properties of novel surface active monomers based on derivatives of 4-hydroxybutyric acid and 6hydroxyhexanoic acid / M. Borzenkov, N. Mitina, V. Lobaz, O. Hevus // J. Surfactants Deterg. - 2015. - Vol.18. - P.133-144.

8. Wuitschik G. Oxetanes in drug discovery: Thesis for the degree of Doctor of Sciences. - Swiss Federal Institute of Technology, Zurich, 2008. - 344 p.

9. Macroinitiators on the basis of new peroxide surface active monomers / A. Kohut R. Fleychuk, O. Hevus, S. Voronov // Chem. Chem. Technol. - 2007. - Vol.1. - P.83-86.

10. Kropf H., Torkler A. Zur Oxiran- und Oxetanspaltung mit Alkylhydroperoxiden an Aluminiumoxid // J. Chem. Res. M. - 1985. - P.2948-2962.

11. Vigo D., Stasi L., Gagliardi S. Synthesis of 3,3disubstituted oxetane building blocks // Tetrahedron Lett. - 2011. - Vol.52. - P.565-567.

12. Yanovskaia N.A., Yufit S.S. Organicheskii sintez v dvukhfaznykh sistemakh. - M.: Khimiya, 1982. - 184 p.

13. Wawzonek S., Matar A., Issidorides C. Monobromopentaerythritol // Org. Synth. - 1963. - Vol.4. - P.681-682.

14. Issidorides C., Matar A. Pentaerythritol derivatives. I. The preparation of pentaerythritol monomethyl ether // J. Am. Chem. Soc. - 1955. - Vol.77. - P.6382-6383.

15. Searles S., Butler C.F. Reactions of alcohols and phenols with trimethylene oxide // J. Am. Chem. Soc. - 1954. - Vol.76. - P.56-58.

Received 03.12.2018 


\section{СИНТЕЗ ПОВЕРХНЕВО-АКТИВНИХ МОНОМЕРІВ I ПЕРОКСИДІВ НА ОСНОВІ ДИЗАМІЩЕНИХ OКСЕТАНIB}

\section{К.І. Кузнецова, В.Б. Вострес, Р.І. Флейчук, О.І. Гевусь}

Синтезовано низку нових поверхнево-активних речовин (ПАР) на основі похідних пентаеритриту та 3,3-дизаміщених оксетанів. Зокрема, при взаємодії бромовмісного дигідроксиалкілпероксиду - похідного пентаеритриту з монометиловим ефіром поліетиленгліколю одержано нейоногенну пероксидовмісну ПАР з поліетиленгліколевим фрагментом. Шляхом послідовних перетворень 2,2-ди[(трет-бутилперокси)метил]пропан-1,3-діолу через стадію утворення дималеїнату за обома гідроксильними групами, подальшим одержанням дихлороангідриду та його взаємодією з поліетиленгліколем одержали цільовий пероксидовмісний поверхнево-активного мономер ряду несиметричних естерів малеӥнової кислоти. ПАР нейоногенного типу, яка містить у складі молекули залишки вищих карбонових кислот та поліетиленгліколевий фрагмент, одержували етерифікацією дигідроксизаміщеного оксетану олеїновою кислотою та наступним розмиканням оксетанового ииклу одержаного диестеру монометиловим ефіром поліетиленгліколю. З'ясовано вплив умов протікання реакцій на вихід і склад продуктів взаємодій. Визначено залежності поверхневого натягу водних розчинів одержаних ПАР від концентрації та значення критичних концентрацій міцелоутворення.

Ключові слова: пентаеритрит, дизаміщені оксетани, пероксидовмісні поверхнево-активні мономери, моноетиловий етер поліетиленгліколю, поверхнево-активні речовини.

\section{SYNTHESIS OF SURFACE-ACTIVE MONOMERS AND PEROXIDES ON THE BASIS OF DISUBSTITUTED OXETANE}

\section{K.I. Kuznetsova, V.B. Vostres, R.I. Fleychuk *, O.I. Hevus}

Lviv Polytechnic National University, Lviv, Ukraine

* e-mail: romanfleych@gmail.com

A series of novel surfactants on the basis of pentaerythritol derivatives and 3,3-disubstituted oxetanes basis was synthesized. Among other substances, a nonionic peroxy surfactant containing a polyethylene glycol fragment was prepared by the interaction of bromo dihydroperoxide (a pentaerythritol derivative) with polyethylene glycol methyl ether. The consequent transformations of 2,2-di/(tertbutylperoxy)methyllpropan-1,3-diol, through the stages of the formation of dimaleate with the participation of two hydroxyl groups, the formation of acyl dichloride and a further reaction with polyethylene glycol, yields a goal peroxy surface-active monomer belonging to asymmetric esters of maleic acid. A nonionic surfactant containing a residual of higher fatty acid and a polyethylene glycol fragment was prepared by the esterification of a dihydroxy substituted oxetane with oleic acid and the subsequent oxetane ring opening of the obtained monoethylated polyethylene glycol diester. The effects of the reaction conditions on the yield and the composition of interaction products were investigated. The dependences of the surface tension of aqueous solutions of the obtained surfactants on their concentrations were established; the values of critical micelle concentrations were determined.

Keywords: pentaerythritol; disubstituted oxetanes; inisurfmer; polyethylene glycol methyl ether; surfactants.

\section{REFERENCES}

1. Malmsten M., Surfactants and polymers in drug delivery. CRC Press, 2002. 368 p.

2. Stoika R.S., Bahatofunktsional'ni nanomaterialy dl'ya biologii i medytsyny: molekuliarnyi dyzain, syntez i zastosuvannia [Multifunctional nanomaterials for biology and medicine: molecular design, synthesis and application]. Naukova Dumka, Kyiv, 2017. 363 p. (in Ukrainian).

3. Hevus O.I., Funktsional'ni poverkhnevo-aktyvni peroxydy $i$ monomery yak reagenty dl'ya oderzhann'ya reaktsiynozdatnykh modyfikatoriv poverkhni [Functional surface active peroxides and monomers for creation of reactive surface modifiers]: thesis for the degree of Doctor of Chemical Sciences, Lviv Polytechnic National University, 2010. (in Ukrainian).

4. Borzenkov M., Hevus O., Surface active monomers. Synthesis, properties, and application. Springer, 2014. 67 p.

5. Yakoviv M., Fihurka N., Nosova N., Samaryk V., Vasylyshyn T., Hermanovych S., Voronov S., Varvarenko S. Researches in amphiphilic properties of copolyesters with chromophore groups. Chemistry \& Chemical Technology, 2018, vol. 12, pp. 318-325.

6. Fleychuk R.I., Kohut A.M., Hevus O.I., Voronov S. Reactive polymers on the basis of functional peroxides. Macromolecular Symposia, 2004, vol. 210, pp. 85-92.

7. Borzenkov M., Mitina N., Lobaz V., Hevus O. Synthesis and properties of novel surface active monomers based on derivatives of 4-hydroxybutyric acid and 6-hydroxyhexanoic acid. Journal of Surfactants and Detergents, 2015, vol. 18, pp. 133-144.

8. Wuitschik G., Oxetanes in drug discovery: thesis for the degree of Doctor of Sciences, Swiss Federal Institute of Technology, Zurich, 2008. 344 p.

9. Kohut A., Fleychuk R., Hevus O., Voronov S. Macroinitiators on the basis of new peroxide surface active monomers. Chemistry \& Chemical Technology, 2007, vol. 1, pp. 83-86.

10. Kropf H., Torkler A. Zur Oxiran- und Oxetanspaltung mit Alkylhydroperoxiden an Aluminiumoxid. Journal of Chemical Research (M), 1985, pp. 2948-2962. (in German).

11. Vigo D., Stasi L., Gagliardi S. Synthesis of 3,3-disubstituted oxetane building blocks. Tetrahedron Letters, 2011, vol. 52, pp. 565-567.

12. Yabnovskaia N.A., Yufit S.S., Organicheskii sintez $v$ dvukhfaznykh sistemakh [Organic synthesis in biphasic systems]. Khimiya, Moscow, 1982. 184 p. (in Russian).

13. Wawzonek S., Matar A., Issidorides C. Monobromopentaerythritol. Organic Syntheses, 1963, vol. 4, pp. 681-682.

14. Issidorides C.H., Matar A.I. Pentaerythritol derivatives. I. The preparation of pentaerythritol monomethyl ether. Journal of the American Chemical Society, 1955, vol. 77, pp. 6382-6383.

15. Searles, S., Butler C.F. Reactions of alcohols and phenols with trimethylene oxide. Journal of the American Chemical Society, 1954, vol. 76, pp. 56-58. 